\title{
The Turn-of-the-century Monument Protection Practice in Light of ERNŐ FOERKS's WORK
}

\author{
Viktor Rozmann ${ }^{1}$ \\ ${ }^{1}$ Institute of Architecture, Szent István University, Budapest, Hungary \\ rozmann.viktor@szie.ybl.hu
}

\begin{abstract}
Present paper is about Ernö Foerk's several architectural works which involved monument preservation. Questions about the theory and practice of monument preservation are surveyed, focusing on restoration and reconstruction in Hungary in the marked period.
\end{abstract}

Keywords: Ernö Foerk, National Committee of Monuments, history of monument protection, reconstruction, restoration, monuments

\section{INTRODUCTION}

As a practicing architect, Ernő Foerk's monument preservation work included reconstruction apart from excavations, measuring and survey. Some representative examples from this segment of his work are introduced below. The projects are not only reflecting Foerk's mindset, but also the approach of monument preservation of his time. From 1911 until his death, he was a regular member of the National Committee of Monuments. He worked in a controversial era, when the modern attitude in the theory of monument protection was increasing, but at the same time the historicist and purist methodology still lived.

\section{BREZNO}

The Lutheran parish of Brezno (Hun: Breznóbánya) commissioned an architectural tender to design a bell tower adjacent to the existing Baroque church. Gyula Sándy together with Foerk prepared two plans for the competition, which contained the new design of the facade adjacent to the turret. One of the plans shows a Baroque style tower with stone-made, dome-like steeple, open-door bell and ornamented gate. The other is Renaissance style, with battlements of the Upper Hungary (Hun: Felvidék) and rich sgraffito decoration. A staircase with an onion dome next to the tower leads to the choir loft. With these plans, they won both the first and the second prizes out of the 13 submissions. There was even a debate among the church leaders about which plan to implement. As a solution, the architects proposed to combine the best solutions from the plans into a third design.

According to Peter Bodo's research [1], in case of this tender, they deviated from their usual working method and worked separately on the two versions. The Baroque plan is mainly Foerk's 
work, while the Renaissance version was drawn by Sándy. On the Baroque submission sheets (currently in the Hungarian Museum of Architecture's Foerk Legacy), both of their signatures can be found, as well as on the coloured construction plans. Its design has a monumental effect, where Foerk applies the Baroque forms confidently.

\section{TWO CHAPELS IN ÓBUDA}

The following year, he prepared a much smaller-scale plan to modify the St. Donat Chapel in Óbuda (now a district of the capital city, formerly a separated town). The Baroque chapel was built on the hillside planted with vines, adjacent to the Farkastorki street in 1781. Today, the chapel is still showing the state of 1905 (Figure 1).

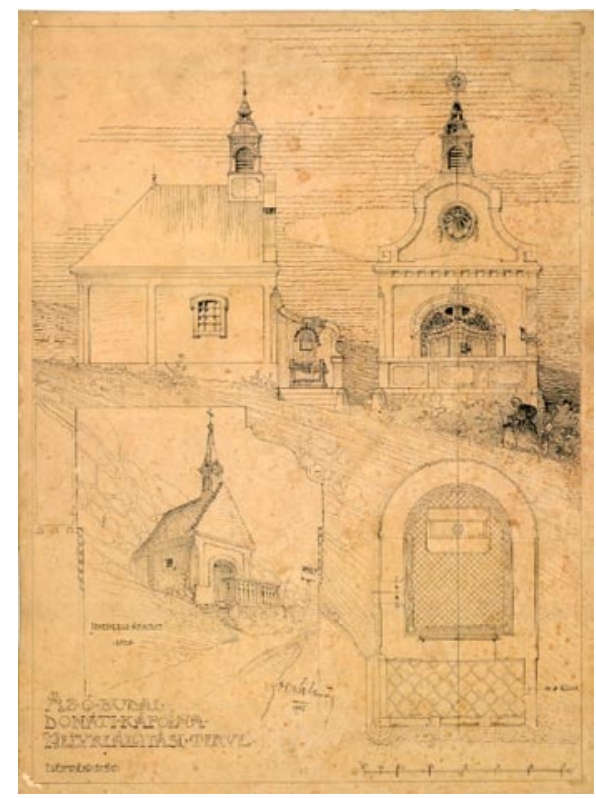

Figure 1. Foerk's plan for restoration of St. Donat Chapel in Óbuda, 1905 [5]

Foerk amplified the Baroque element of the chapel. He designed an angular fronton with curved top and volutes instead of the original, plain one. He also replaced the simple, but wellproportioned, slender bell tower with a more articular Baroque structure. Although the task seems almost insignificant, he did not overlook the minor details: he enlarged the window on the side-façade and extended it with a more prominent belt frame, replaced the sawed corselet of the patio to stone in front of the chapel, added a sweeping wall to the right side of the façade which ends in a volute. On this wall, a semi-circular, notched, metal sheet roof is placed, under which a Madonna picture and a prie-dieu can be found. Instead of the simple gate, he designed an ornamented, open, wrought iron one referring to the ripe Baroque style. Foerk's power of design, and the desire to do grew greatly beyond the dimensions of a simple vineyard votive chapel, which can be clearly perceived on such details, as the drawing of the gate and fronton, picturing the pigeon of Holy Spirit appearing in radial frame decorated with flowers.

A somewhat more moderate, but equally sophisticated designer attitude is shown in case of the small-scale Holy Blood Chapel of Óbuda, Kiscell Calvary, which plans he completed in 1910. The stations of the cross begin adjacent to the former Trinitarian monastery, ending at 
this chapel built in 1822. The new façade was designed by Foerk in 1910.

The building burned down in the 1980's, then renovated in a simplified manner. If the original drawing of the main and side facades are compared to the archive photos, it can be concluded, that Foerk's plans were realised here, unlike in case of the St Donat Chapel. The previous state of the chapel is unknown, but the plans show that Foerk's attention extended to every detail. Here also, the middle of the curved and angular fronton, the sunk, festooned main motif can be found. Above the saddle, the powerful and detailed bell tower is placed.

\section{NAGYKÖRÖS}

A significantly larger task was the remodelling of the Nagykörös Calvinist Church tower. The fire alarm service was transferred here from the guard tower in 1890 due to its larger height. The medieval church tower was previously stuck by lighting, thus the steeple was replaced in 1758 with an octagonal, onion-shaped roof covered by red shingles. This old, damaged $18^{\text {th }}$ century steeple was to be replaced in the design contest commissioned by the parish in 1906 . The design of Ernő Foerk and Gyula Sándy came out as winner of the tender with their plan named 'Rooster'. The calling for the tender stated that the new tower should remain suitable for the fire alarm service. Their plan heightened the tower by 9 metres, added pinnacles to the buttresses, and a round balcony. Keeping the form of the previous octagonal, Baroque steeple, they designed a large, two-storey superstructure including the four cornered, arched fire alarm balcony, with pinnacles and copper coating (Figure 2). The original plan in the end was built with some simplifications: the pinnacles were spared, but a second, open patio level was added. The architecture and the volume of the new turret seems to exceed the dimensions of the turnof-the-century Alföld (lowland of Hungary) settlement, being the tallest building in the county even today.

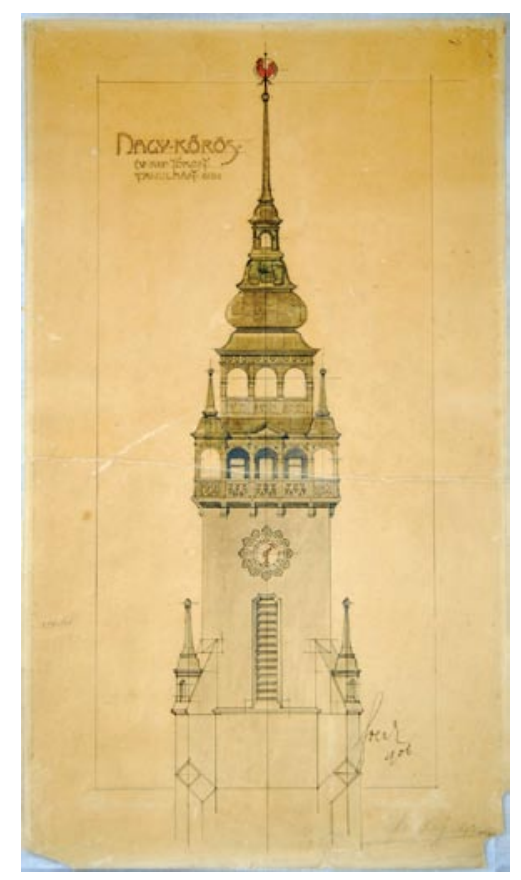

Figure 2. Foerk and Sándy's tender plan called 'Rooster' for reconstruction of Calcinist Church tower in Nagykőrös, 1906 [5] 


\section{BELTIUG}

An even greater intervention happened in case of the medieval church of Beltiug (Hun: Krasznabéltek), which was extensively reconstructed and enlarged between 1911-13 by Foerk's plans (Figure 3). The details of the medieval architectural history of the church is known from the results of wall excavations carried out in the remaining parts of the building in 2011.[2] The medieval appearance of the church is shown on a pre-1862 illustration.[3] On that picture, the pre-reconstruction floor plan and south façade can be perceived. In the aforementioned Foerk Legacy, the drawing of the tower in its 1911 state can be found, picturing an onion steeple in place of the previous pyramidal form, which is probably added after the 1862 fire.

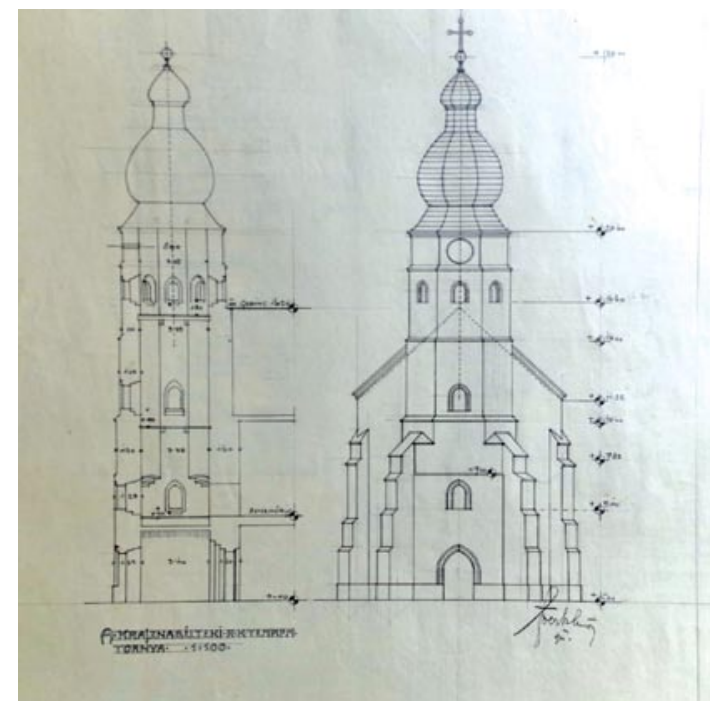

Figure 3. Section of the tower and western façade survey of Beltiug Church before reconstruction and enlarging, 1911 [5]

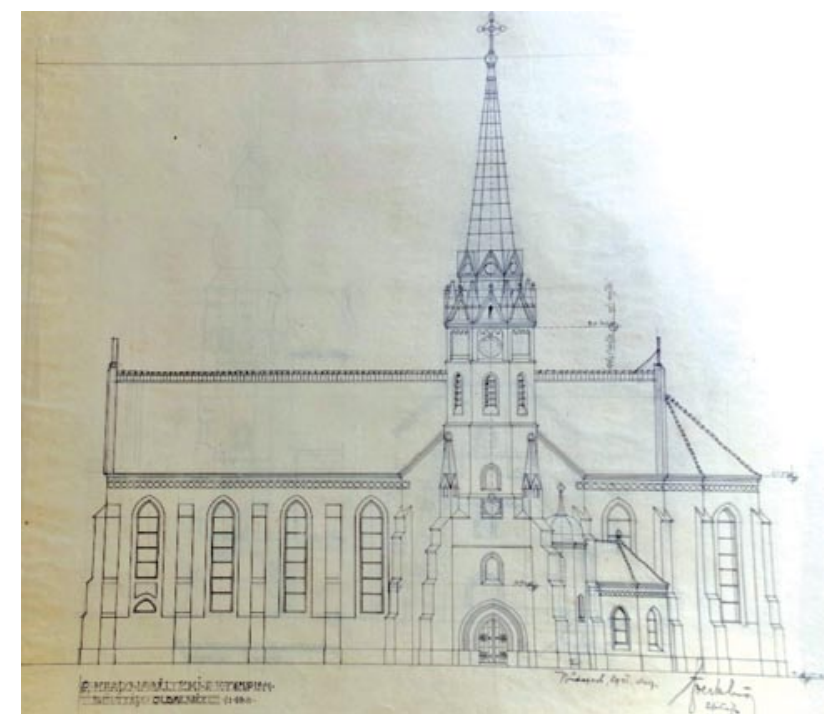

Figure 4. Foerk's plan for reconstruction and enlarging Beltiug Church, 1911 [5] 
During the reconstruction, according to Foerk's plan, the medieval church's aisle was almost completely demolished, replaced by a new aisle with North-South axis, thus perpendicular to the original shape. The only remaining part is a short section of the western side of the original building. The sanctuary was also preserved, now used as an eastern side chapel. Apart from the new ledge, and except one remaining window, which was not walled up, the sanctuary is in its original form. (Szilárd Papp, who has studied the original, pre-reconstruction drawing draws attention to the fact that the main ledge of the sanctuary is still illustrated as its probably original, medieval form, from which we can conclude that Foerk designed the new ledge for the sanctuary [3])

The medieval tower of the church also remained, but its exterior was partially modified. The corner buttresses received pinnacles, the gothic arched windows of the bell were elongated by tearing down the parapets, and also, Foerk replaced the former, simple, grading framed with nested arched gate. He designed a spirelet onto the axis of the roof of the new aisle and the original sanctuary. (Figure 4) The in-style modification of the church was without any scientific and research basis, thus the final result is misleading.

\section{SZEGED}

A smaller scale, but more significant monument preservation works was the reconstruction of the St Demeter Tower in Szeged. The demolition of the church was overlooked by Károly Cs. Sebestyén, as the delegate of the City Museum. In his earliest report about the finding of the medieval tower remains, the in-style rebuilding of the third window line was mentioned [4]. Sebestyén himself also made drawings about the reconstruction of the tower, which are essentially agreeing with Foerk's plan. A report from the construction states that chosen stone remains from the collection of Museum's Lapidarium palace should be utilized, an ossuary to be created in the underground part of the tower, and also the ground level to be built as a chapel. The tower was thus restored by the plans of Foerk, parallel to the construction of the dome.

The third floor was partially reconstructed from original bricks. At this time, the western entrance gate, the secondary sited stone lamb were placed. Additionally, a Horthy monument was put on the north side, which since had been demolished. In a letter dated August 1926, Sebestyén complained to Foerk and the MOB (National Commission of Monuments; Hun: Múemlékek Országos Bizottsága), that the reconstruction of the tower is going differently from his plans [5]. In the response letter of the MOB, the official statement concerning the monument restoration/reconstruction is worded: 'The Commission has, of course, taken the principle that the monuments should preferably been preserved in their original form. And, even if in case of the tower in Szeged, an exception is made, it is only apparent. The case of the tower is, that the original shape is unknown. (...) In these circumstances, the aesthetic aspect of the issue is more important compared to the aspect of historicity, which in any way cannot be definitely clarified without any doubt.' Although the previous shape of the third row of windows is not known, its structure was based in some sort of hypothesis and could be considered as reconstruction, as part of the rebuilding of a previously existing building.

\section{ÓcsA}

A pre-existing condition or a reference to it have though not always been a condition for a tower to be heightened. The Calvinist Church of Ócsa have initiated the elevation of the Premonstratensians monastery $\left(13^{\text {th }}\right.$ century $)$ towers, or the construction of a crossing tower 
already before the World War 1. Based on results of the thorough research of the building, it is most likely, that the church has never had a three-story tower [6].

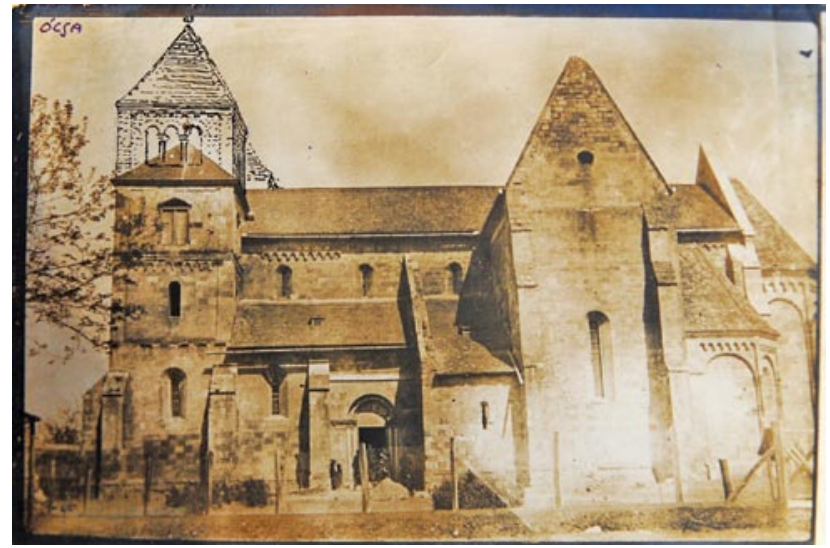

Figure 5. Probably the very first sketch of heightening of towers of Cavinist Church of Ócsa, around 1922 [5]

With the restoration of the church started in 1921, the question was re-launched, and was debated in a MOB session. Otto Sztehló, an architect of the MOB proposed the construction of the crossing tower (Figure 6), while István Möller (another monument preservation expert architect, member of MOB) suggested the heightening of the western towers with wooden structure. Foerk opposed the latter, as in his opinion, it would result in a foreign, German character (Figure 5). He instead recommended that the towers be elevated by stone or even bricks. In the end, the Commission favoured the rise of the tower by stone or bricks. In the finished, detailed plans, Foerk decided to build them of stone. The construction work, including the interior renovation was completed in 1924.

Concerning the heightening of the Ócsa church towers, István Möller articulated, that 'a newelement should not be included in the historical part if the monument and the old structure should not be continued by repeating the old forms. The capital of the columns should remain in their present state, even the layer of lime should not be scraped off. All new layers of stoned masonry should be marked with the ' $F$ ' as Facsimile (replica) sign and the year of placement.'[7]

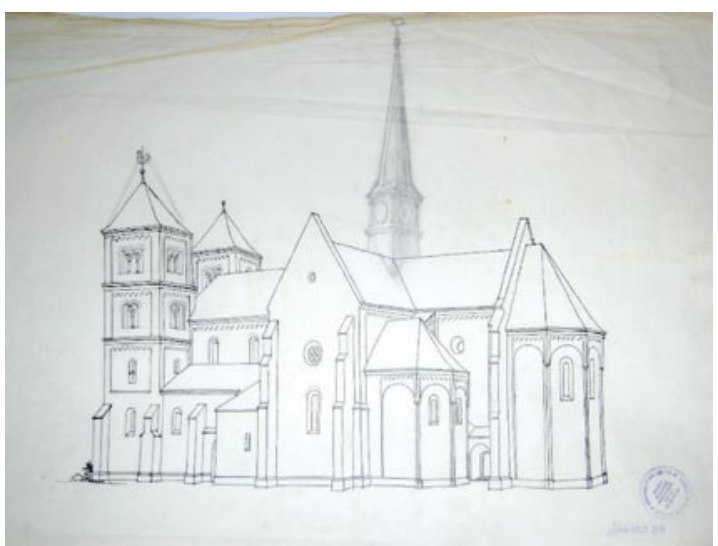

Figure 6. Another plan for the restoration of Calvinist Church in Ócsa: sketch of a crossing tower and heightening of towers, around 1922 [5] 


\section{POPRAD}

Theory and practice however, like some many times, are separated in the works of Foerk. As an example, he proposed a similar solution for the enlargement of the Poprad Roman Catholic Church, that he did in case of Krasznabéltek, detailed above. He designed three variations for the extension of the small, two-aisle church with façade tower. The three versions differ only in detail. The basic concept of all three design variants is that he tears down of the northern and southern walls, the entrance hall and the choir loft of the original aisle, and extends the remaining parts with a new sanctuary from the north, a new part of aisle and entrance hall from the south (Figure 7). This makes a side chapel from the existing sanctuary. All three versions integrates the bell tower standing separately in the south, into the main volume. Also, all variants uses filigree, but richly decorated spirelet on the roof, in axis of the old sanctuary and tower (Figure 8). He changes the shape of the steeple, designed Gothic style windows with tracery and nested arched portal as entrance. He covered the new aisle with Gothic rib vaults.

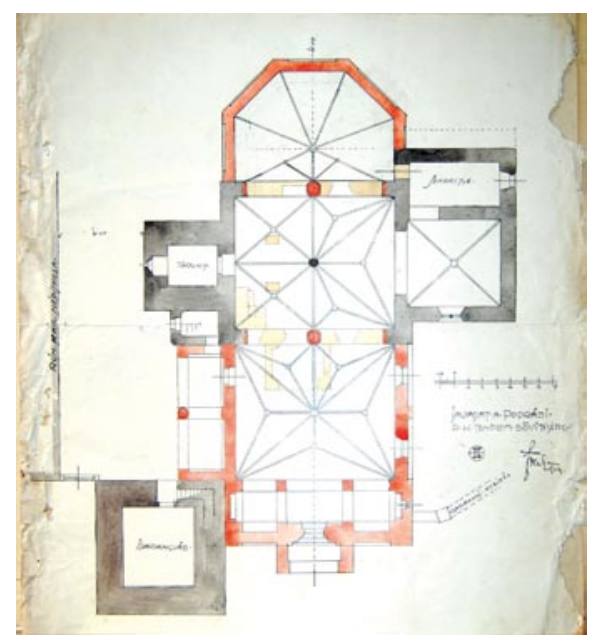

Figure 7. Foerk’s plan for reconstruction of Poprad Roman Catholic Church, version № 3, 1915 [5]

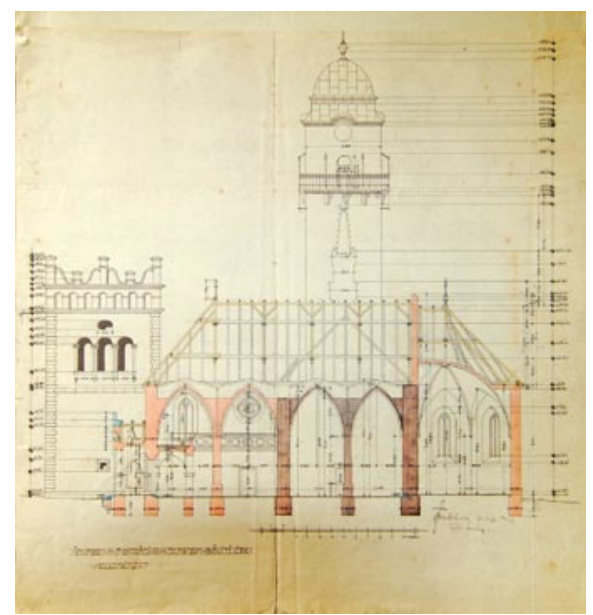

Figure 8. Foerk's plan for reconstruction of Poprad Roman Catholic Church, longitudinal section, 1915 (source: Hungarian Museum of Architecture's Foerk Legacy without inventory number) 
The detail of the plans and the large number of drawing sheets imply a real assignment, the realisation most certainly prevented by the World War 1 . The enlargement plan with serious demolitions liberally overlooking the interior painting of the church, which was already known in Foerk's time.

\section{CONCLUSION}

The plan of the above Krasznabéltek and Poprad church enlargement was not a unique idea of the time. In the first three decade of the $20^{\text {th }}$ century, such requests were constantly on the MOB agenda [8]. Following the period of the great and spectacular reconstructions, applications of multiple medieval village churches were on the Commission's table. The boldness of the solutions presented above can be explained by the fact that in that time, the medieval origins of a church itself was not sufficient reason to become protected monument. It should be noted however, that among the eight buildings introduced above, five was listed in the Gerecze heritage list of 1905 [9]. The exceptions are the Breznóbánya Baroque church and the two Óbuda chapels. Although the modern approach to the monument protection had been increasingly strengthened during the presidency of Baron Gyula Forster (1906-1922), in the work of Foerk, who was a Friedrich von Schmidt (architect, worked in late 19th century in Vienna; his last work was the restoration of the cathedral in Pécs in Hungary; he was teacher of young Foerk) disciple, the purist and historicist tendencies of the turn-of-the-century continued to live. In case of monument reconstructions, he did not hesitate to use his architectural qualities to design in-style. He sought to realize an ideal design, the sometimes damaged, truncated reality of the building itself, formed by historical process did not tie his hands. He regarded the existing building as raw material, and tried to mend, to improve, elevate it to the European standard of construction to the best of his knowledge. In the light of his above presented plans, it is sometimes difficult to decide, whether he was more a study scientist, or a creative artist during working. Just two years after Tibor Gerevich (art historian, president of MOB between 1934-1949. During his presidency strengthened the modern attitudes in monument preservation) received the MOB presidential seat, Foerk departed from the ranks of the living, as seemingly symbolic change of an era.

\section{REFERENCES}

[1] Bodó Péter: Sándy Gyula építészete 1914-ig. Szakdolgozat. Piliscsaba, 2010

[2] Terdik Szilveszter: A krasznabélteki és az erdődi templom újjáépítése a XVIII. században. Online source: http:// byzantinohungarica.hu/sites/default/files/_18-Terdik_Szilveszter.pdf (Last downloaded: 2019.01.04.)

[3] Papp Szilárd: Krasznabéltek, római katolikus templom. Online source: http://www.temple-tour.eu/files/50/szinopszis_ hu.pdf (Last downloaded: 2019. 01. 04.)

[4] Cs. Sebestyén Károly: A szegedi Szent Demeter templom bontása. Dolgozatok. Szeged, 1925

[5] Hungarian Museum of Architecture's Foerk Legacy (Hun: Magyar Építészeti Múzeum, MÉM) without inventory number

[6] Lukács Zsuzsa - Juan Cabello - Csengel Péter: Az ócsai premontrei prépostság kutatása. in: Müemlékvédelmi Szemle. szerk: Dvorszky Hedvig - F. Mentényi Klára. 1991/1. Budapest, Országos Mủemléki Felügyelőség, p. 16-19.

[7] Granasztóiné Gyỏrffy Katalin: A Müemlékek Országos Bizottságának tevékenysége a trianoni békekötés után (1920-1934). in: A magyar mủemlékvédelem korszakai. Tanulmányok. szerk: Bardoly István - Haris Andrea. Országos Müemlékvédelmi Hivatal, 1996. p. 160-161.

[8] Granasztóiné Győrffy Katalin's work cited above

[9] Gerecze Péter: A müemlékek helyrajzi jegyzéke és irodalma. Magyarország Mủemlékei, 2. 1906.; Gerecze Péter: Magyarország régi falképeinek jegyzéke és irodalma. Magyarország Müemlékei, 1. 1905. 485-550.; (Péter Gerecze noted preservation professional, member of MOB) 